\title{
Not in our community: Queer women challenge religious homophobia in rural Kentucky
}

\section{Bernadette Barton \& Ashley Currier}

To cite this article: Bernadette Barton \& Ashley Currier (2019): Not in our community: Queer women challenge religious homophobia in rural Kentucky, Journal of Lesbian Studies, DOI: 10.1080/10894160.2019.1677080

To link to this article: https://doi.org/10.1080/10894160.2019.1677080

\section{Published online: 21 Oct 2019.}

Submit your article to this journal

Q View related articles ¿

View Crossmark data $₫$ 


\title{
Not in our community: Queer women challenge religious homophobia in rural Kentucky
}

\author{
Bernadette Barton $^{\mathrm{a}}$ and Ashley Currier ${ }^{\mathrm{b}}$ \\ ${ }^{a}$ Department of Sociology, Social Work, and Criminology, Morehead State University, Morehead, \\ Kentucky, USA; 'Department of Women's, Gender, and Sexuality Studies, University of Cincinnati, \\ Cincinnati, Ohio, USA
}

\begin{abstract}
"Not in my backyard" (NIMBY) movements emerge when a social or political event spurs opposition from local residents. Much research on NIMBY movements concentrates on local residents' efforts to defend their community from unwanted "outsiders" or elements, such as a waste incinerator or sex offenders. Little is written on how NIMBY activism can redefine a place to be more inclusive of sexual minorities and supportive of progressive social initiatives. After the Supreme Court's 2015 ruling in favor of marriage equality in Obergefell v. Hodges, Rowan County Clerk Kim Davis refused to issue marriage licenses to same-sex couples citing her religious beliefs. Davis' actions galvanized marriage-equality and religious-freedom activists in the region. Pro-marriage-equality activists included lesbian, bisexual, pansexual, and queer women who viewed Davis' action as an attack on their legitimacy in the community. Drawing on 11 interviews with queer women in Kentucky, we explore how their activist work in Rowan County challenged small-town intolerance and religious homophobia and helped to re-form the region as more a progressive space for sexual minorities.
\end{abstract}

\section{KEYWORDS}

Kentucky; Kim Davis; lesbian activism; marriage equality; not in my backyard (NIMBY) activism; religious freedom; rural queer studies

\section{Introduction}

The June 2015 Supreme Court ruling Obergefell v. Hodges found state marriage bans on same-sex marriages unconstitutional. Directly following this decision, Kentucky made national news when Rowan County Clerk Kim Davis refused to issue marriage licenses to same-sex couples, citing a conflict of faith. Like their counterparts in urban areas (Bernstein \& Taylor, 2013), rural lesbian, gay, bisexual, transgender, and queer (LGBTQ) (LGBTQ) residents and supportive heterosexual allies immediately began picketing outside Davis's office. They swiftly established the Rowan County Rights Coalition (RCRC), a face-to face and online activist organization. RCRC members included residents from Rowan and neighboring counties 
and Morehead State University (MSU) faculty, staff, and students. Rowan County also houses many Davis supporters who considered her actions a testament to her Christian faith. Led by pastors and members of local churches, a loose coalition of religious-freedom activists quickly rallied, motivated both by Davis' action and the religious homophobia institutionalized in many conservative Christian churches (Apostolic, Church of Christ, Baptist, and non-denominational among others) throughout the region (Barton, 2012). The two groups protested outside the Rowan County courthouse for weeks.

Among socially conservative Kentucky towns, Morehead, the Rowan County seat, is a progressive enclave and a destination spot for many LGBTQ people from Appalachia. Home to a rural community of artists, farmers, and university employees, few residents expected Morehead to host a battle in the "culture wars." In this article, we explore how Davis's actions and the subsequent protests transformed Rowan County for LGBTQ people. Citing their disagreement with Davis' stance, lesbian, bisexual, pansexual, and queer women participants viewed activism as a way to combat homophobia in their community. We treat their activism as a form of "not in my backyard" (NIMBY) mobilization. In doing so, we challenge the scholarly tendency to ignore queer lives in rural spaces (Stone, 2018) by illustrating how NIMBY organizing can be a viable strategy to create progressive social change for rural queer people.

Methods comprise eleven interviews with white lesbian, bisexual, queer, and pansexual women who participated in the courthouse protests. ${ }^{1}$ Our data include face-to-face, digitally recorded audio interviews with seven women and four transcribed interviews collected by researchers involved with MSU's Rowan County Marriage Equality and Religious Liberty Project (MERL). We conducted interviews with anti- and pro-marriage-equality protesters in 2017-2018, and MERL interviews were collected in 2016-2017. We assigned interviewed women pseudonyms to ensure their confidentiality. Interview questions explored participants' thoughts about and experiences of the courthouse protests, the role of RCRC, and the effects of the 2015 events in Rowan County.

\section{Making space for sexuality in analyses of NIMBY organizing}

What is the relationship between LGBTQ activism and NIMBY organizing? Most studies on NIMBY organizing explore how residents object to a group, event, or institution menacing their communities (Stein, 2001). Describing how political contexts affect social movements, McAdam and Tarrow (2018, p. 32) write that "reactive, NIMBY-style, collective action against all manner of perceived threats, remains perhaps the single most common type of protest world-wide." Much research on NIMBY 
movements concentrates on residents' reactive efforts to defend communities from unwanted "outsiders," such as registered sex offenders (Williams, 2018) or environmentally harmful projects (Hager \& Haddad, 2015). When scholars research sexuality in NIMBY organizing, they often focus on conservative mobilization in urban spaces. For example, in the US, some evangelical Christians have initiated vigilante-style "backyard abolitionism" to find victims of human-trafficking and eliminate commercial prostitution from their communities (Shih, 2016).

LGBTQ-led NIMBY organizing in urban queer spaces can also be motivated by intolerance, such as when privileged lesbians and gay men wage class-based battles over access to and the reputations of LGBTQ spaces (Jerolmack \& Walker, 2018). For example, in some LGBTQ urban neighborhoods, white, wealthy lesbian and gay residents eject poor, working-class queers and queer residents of color by organizing to criminalize public behavior like loitering or solicitation for sex (Ross, 2010). In other affluent, gay urban enclaves, privileged community members have blocked shelters for homeless queer youth (Cruz, 2011). Manalansan (2005, p. 142) explains that well-off white gay and lesbian residents' NIMBY organizing ushers in "homonormativity" by "anesthetiz[ing] queer communities into passively accepting alternative forms of inequality in return for domestic privacy and the freedom to consume." In other words, "gating" their communities allows privileged, white lesbian and gay elites to ignore racial and class inequalities that make life difficult for LGBTQ residents of color.

Rural queer studies offer ways to understand NIMBY organizing in rural LGBTQ communities. First, these approaches examine how queer residents feel connected to their "close-knit" communities (Kazyak, 2011, p. 573; Luis, 2018), for instance, through friendships among lesbians (Forstie, 2018). Brown-Saracino (2018, p. 198) characterization of how small cities influence lesbian, bisexual, and queer women's sexualities contests "metronormative" narratives that dominate queer studies. Halberstam (2005, p. 36) defines "metronormative" perspectives as casting "[r]ural and small-town queer life... as sad and lonely." The willingness of lesbian, bisexual, pansexual, and queer women to stay in and fight for acceptance in their communities challenges metronormative narratives. Second, rural queer studies approaches allow scholars to consider rural lesbian and queer women's NIMBY organizing as a key process in both generating a "close-knit" community and remaking their town to better include lesbian and queer difference.

\section{Findings}

Participants expressed that the events of 2015 had a lasting impact on Rowan County and noted ways that the protests changed the community. Primarily, 
many LGBTQ people shed the "toxic closet" (Barton, 2012), became more visible in their home county, found one another, and participated in a public conversation about LGBTQ rights. Staunch heterosexual allies also fought alongside LGBTQ people for marriage equality, bolstering lesbian, bisexual, pansexual, and queer women participants' sense of belonging and community. The months-long protests at the courthouse also offered progressive residents opportunities to meet and connect, laying a foundation for future grassroots organizing.

Interview participants acknowledged class inequalities, rejected regional prejudices about rural Appalachian communities, and actively challenged stereotypes of Kentucky as culturally "backward" (Donesky, 1999, p. 295). Like other queer people committed to their rural homes (Gray, 2009; Staley, 2012), the women featured in this article wanted to transform not leave their community. Lesbian, bisexual, pansexual, and queer women activists' experiences illustrate both how "places make us" (Brown-Saracino, 2018, p. 198) and how activism makes places. All observed that pro- and anti-LGBTQ protestors maintained a respectful civility until outsiders entered Rowan County at which point tensions between protest groups escalated. We analyze the NIMBY tactics lesbian, bisexual, pansexual, and queer women used to confront religious homophobia in their community.

\section{Dissolving the "toxic closet"}

Participating in pro-LGBTQ demonstrations at the courthouse helped lesbian, bisexual, pansexual, and queer women dismantle the "toxic closet," a homophobic socialization "to hold back, to not express ourselves, to accept that we do not deserve the taken-for-granted social courtesies, legal rights, respect, care, and support that heterosexuals enjoy without thought" (Barton, 2012, p. 88). They also brought people together in ways that furthered LGBTQ rights and facilitated a richer public conversation about sexual and gender minorities. For example, Caroline, a lesbian said, "We're less invisible and it's more comfortable to talk about" LGBTQ experiences. Sydney, a lesbian, admitted,

It was a conversation we needed to have in Morehead. So, Kim Davis, I'll pat her on the back for allowing that to happen. Because if you were in Morehead, you pretty much had to be closeted. I think that [the protests] opened that up a little bit. It also brought the conversation out and made it more explicit. So we're now dealing with it. ... So, I'm really proud of what happened.

Like Sydney, Kristen, a lesbian, believed the events increased local LGBTQ visibility and forced community members to reckon with LGBTQ issues. She said, "It made people more aware of our rights, that we're here and we're not going away." 
The fact that the early days of the demonstrations were mostly positive, empowering, and civil encouraged participants to protest as "out" lesbian, bisexual, pansexual, and queer women. Terry, a lesbian, and Christine, who is pansexual, each described the environment. Terry narrated:

Well, the first day [early July 2015], it was fun. Friends, people I hadn't seen in a long time, are showing up and there's flowers and signs. Lots of rainbows. I've had people show up in support. So it was, "What do we do here? We stand, okay. Oh, let's chant. Yeah, good. I don't want to chant. Let's all hold hands." It was interesting. Fun. Hot.

Christine rushed to her first protest without saying "bye to my significant other. I just went on down there, and it was pretty active already." She recalled seeing a number of marriage-equality supporters at the courthouse and that Kim Davis's "people had started to congregate as well." She said, "By mid-day, she had people there representing her and her theology and her "right to do as she saw fit in accordance with her beliefs." Although Christine observed a "lot of energy on both sides," she emphasized the "passion" marriage-equality activists displayed, and was determined to show up and support "our friends trying to pursue their right to get married [and] protect themselves."

Most participants expressed that it was important to demonstrate for those who couldn't-those who were closeted, scared, young, and struggling. Caroline shared that she was "stunned" and then filled with "joy" when she first learned about the Supreme Court decision legalizing samesex marriage, knowing she would be able to marry in her hometown. She said, "People getting married [in Kentucky] the same day that it became legal was astounding." Outrage complicated Caroline's joy when she learned that Kim Davis was refusing marriage licenses to same-sex couples in Rowan County. Caroline explained she was inspired to join the "movement" because, she said, "This is a place that matters. Being from the area, it was something I knew I had to do." She understood her involvement as a "responsibility" to the "young people in the area that are LGBTQ that I'm related to and that I love, who aren't able to easily make a stand because of who their family is or what their relationships are." For Caroline, allowing the religious homophobia of Davis and her supporters to go unopposed further marginalized LGBTQ youth.

Alice, a lesbian, also explained that "there are kids in our community who have said, 'I can't go home because I came out as gay or lesbian and my family has shunned me,' or 'if I came out, my family would never speak to me again." A middle-aged woman with a stable job, Alice felt securely enough positioned to "stand up for those who can't." Similarly, Terry expressed her commitment to join the groups standing up against bigotry for "little dudes in Eastern Kentucky:" 
I protested because I wanted people in the community to know that it wasn't just one person that was interested in this. I was there because the [college LGBTQ student group], affirmative action statements, LGBT offices, Pride events, protesting, to me, those are beacons. Beacons of light for curly-haired girls that live in [a town south of Morehead] that think that not only is the world against them, but their entire religious system is against them. Or for little dudes that live in far eastern Kentucky that haven't had the opportunity to tell their parents, "Hey, I'm gay," and for them to be like, "That is so awesome! I love you! Your boyfriend is amazing!" I will stand out there so you know that people like me exist.

Terry hoped that the work of a diverse group of LGBTQ rights and marriage-equality supporters might make the future a little brighter for sexual and gender minorities in the region.

Lesbian, bisexual, pansexual, and queer women recognized and appreciated the hard work and fierce support of many heterosexual allies in RCRC. "Allies are movement adherents who are not direct beneficiaries of the movements they support and do not have expectations of such benefits" (Myers, 2008, p. 168). For example, informants explained that heterosexuals helped found RCRC and stood side by side with LGBTQ people outside the courthouse day after day in the summer heat. Caroline described the heterosexual allies as:

the group of people who showed up to protest and who kept showing up and who organized and helped walk people in as they went to the courthouse. They were there to support us. They called and said, "We've got your back and don't worry about this." [They were] group of local citizens, again, most of them not gay, not a part of the queer community but just really unhappy with the fact that this injustice was happening in our community and were willing to come out and bodily put themselves between us and harm. That's really the truth of it. To make sure that justice was done and to say this is not the kind of community we want.

Participants found this solidarity with supportive heterosexuals very meaningful and some, like Caroline, experienced a new level of community support. Caroline and her partner Savannah obtained a marriage license at the Rowan County courthouse while Davis was in jail. She said, "There was a moment that was really surreal and felt full circle for me. I could look down the street and see where my grandmother lived most of my life. It's probably the most accepted or the most belonging I had ever felt."

Natalie, an RCRC leader, and daily regular at the demonstrations, observed LGBTQ people in the region actually discover themselves and one another in front of the Rowan County courthouse. She explained, "People felt like [the protests] gave them a voice that they didn't have: 'I thought I was the only one in Morehead, but I'm not. Look at all these people who came out.' Especially transgender individuals. We ended up finding a whole pocket who identified as transgender and they found each other because of this." The demonstrations for marriage equality created a space where 
sexual and gender minorities came, met one another, and formed support networks.

\section{How NIMBY activism transformed this rural Kentucky town}

From early July through mid-August 2015, relations between the proequality and religious-freedom protestors were cordial as small-town norms of civility governed their interactions. Natalie explained:

You have generations of families here, and this divided us even within families. So you would protest each other during the day, but then you have to go church with them on Sunday. Or you're going to Kroger [grocery store], and they're there. You can't escape them. It's not a big city where you can disappear. These were people that you saw every day.

Protestors on both sides of the sidewalk recognized the importance of being neighborly. According to the 2010 census data, Rowan County has 24,517 residents. It is stressful to share a town with, and regularly encounter, those with whom one has unresolved tension. Both marriage-equality and religious-freedom demonstrators knew that, when the dust settled, they still had to work and live together.

Yet, when several same-sex couples and one opposite-sex couple who were denied marriage licenses sued Davis and outsiders arrived, local norms of courtesy were upended. The case made its way to an appeals court in Ashland, Kentucky, where a federal judge ordered Davis to issue marriage licenses to all couples, including same-sex couples (Associated Press, 2015; Southall, 2015). Davis refused and the judge ordered her to jail. When Davis was incarcerated, churches from outside Rowan County began bussing in religious-freedom protestors to Morehead. At this point the tone of the courthouse protests changed, and "things got scary" for participants like Terry. She explained, "We had reports of this armed militia on its way in." Emulating a hypothetical, armed religious-freedom supporter, Terry grabbed an imaginary belt recalling that they "were going to show the police chief what they were going to do."”

During this time, Alice and her then-partner (and now wife) Kristen went to get their licenses. The courthouse was, as Alice described, "a media circus":

There were tents with different media outlets. There was MSNBC, CNN, MBC, CBS. There were Lexington outlets. There were helicopters flying over top because they had heard that at noon, we were coming to get our licenses that day. The AP [Associated Press] person had called me and said, "When are you coming? We thought you would be at eight this morning. When are you coming?" And I said, "It'll be around noon. I'm working." And so Kristen and I went down there and helicopters flying over-I mean that's just shocking that there were news helicopters in Morehead, Kentucky. And I was the subject of those helicopters. And there were 
protesters. There were protesters for both sides. There were people who were passing out flowers. There were ministers willing to marry us right there and invited us to church in Lexington. There were people yelling, "You're going to hell," "It's against the rules in the Bible," and "You're going to burn," and sodomy-it always something about sodomy.

With media vans and busloads of strangers appearing, protests grew more raucous and contentious. Terry recalled seeing "people playing drums and trumpets, stomping around, and retirees in camping chairs with Bible verses. They were saying things that are very hurtful to people who've already been ostracized and bringing guns into this." Deborah, a lesbian, explained that she felt very unsafe the day that men brought guns strapped to their backs to the courthouse. She also described a disturbing encounter with a Davis supporter: "One man got in my face and said, "The reason you're a lesbian is because you were raped as an infant." Several informants described two vans painted with Bible verses, featuring lurid antiabortion images and proclaiming AIDS as God's punishment for "homosexuals," parked in visible areas around town. Terry was particularly bothered by a plane with a banner advertising an anti-LGBTQ movie promoting conversion therapy flying across Rowan County at all times of the day. Overall, informants noted a decline in respectful protest norms when outsiders entered Rowan County. Davis supporters bussed in from North Carolina and Tennessee churches had no investment in the place, no expectation of a continued relationship with the people on the other side, and thus no social pressure to be respectful.

Lesbian, bisexual, pansexual, and queer women participants overwhelmingly perceived Davis supporters as more aggressive and insulting than marriage-equality proponents. However, they did note that LGBTQ activists from outside Morehead were sometimes more confrontational than RCRC preferred. Anticipating possibly belligerent counterprotestors, some of whom would likely espouse homophobic ideas, RCRC leaders developed a set of protest "guidelines" in early July. Natalie and other RCRC representatives shared the "rules" with new people rotating in and out of the demonstrations. For example, one guideline forbade "vulgarity." She said, "We're going to be representing our community. We need to be able to be respectful and responsible." Natalie explained that RCRC members wrote the rules "on the back of our posters so if people showed up, we could give them a poster, and they had the guidelines on the back so they can see where we were coming from."

Not only did these rules help protestors cultivate a "collective identity" rooted in defending LGBTQ rights and marriage equality in Kentucky (Taylor \& Whittier, 1992), but they also projected an image of marriage-equality supporters as "respectful and responsible" community members. However, like the 
religious-freedom protestors arriving from other states, some progressive outsiders also showed little interest in abiding by the RCRC rules of civility. Natalie illustrated, "I remember there was this one woman in particular, and I gave her a sign and I said, 'The media is watching us so it's really important that we stay focused and here are some guidelines that we came up with so this can be helpful.' And she was not having it. She wanted to fight and was ready and willing to engage with anybody."

As protests and media scrutiny became somewhat routine, Rowan County residents had new conversations about LGBTQ rights with one another. Respondents like Christine used the events to initiate dialogs with those opposed to or ignorant about LGBTQ rights. She recalled that "a lot of friendships ended up being broken off because of people trying to defend what [Davis] was doing, asking questions like, 'Why can't [couples] go to another courthouse? Why does it have to be here [where Davis] signs the license?"' Yet, over time, Christine observed some people change from being supportive to critical of Davis as they mulled over the implications of her actions. Christine described one interaction: "You know, you're right. It isn't right that she did that.' These are people ... 50-, 60-year-old men and women. ... All you needed to say was: 'These are our rights. These are the things that we get from this-like what if the spouse dies?" Christine was even able to "have that conversation with" her "own grandparents ... and have them see what [Davis was] doing isn't right." Although it was taxing for Rowan County residents to be ground zero in the battle over marriage equality, those featured in this manuscript observed many positive developments explicitly manifest because the NIMBY protests happened in a rural place.

\section{Fueling and dismantling stereotypes about Appalachia}

Over the summer and fall of 2015, international news outlets ridiculed the appearances of Kim Davis and her husband, Joe Davis, and dozens of satirical memes of Davis circulated on social media. Clerk Davis, with her uncut hair, lack of makeup, long skirts, four marriages, and bigoted ideas about gay people was easy to mock. Bethany, a bisexual woman, noted how

the media fixated on her [Davis], like a trend, a flash. She physically embodied and religiously embodied a stereotype that drew a lot of media attention. She practices an Apostolic religion that's charismatic in which women don't cut their hair and always wear skirts. So, I think all of that was easy for the media to fixate on as freakish.

Although Bethany did not agree with Davis' actions, she deplored how the media and US public vilified her: "I didn't appreciate any of the snarky memes floating around, making fun of the way she looked at all. But I think that exotic visual look was very arresting to media folks from New 
York and California." Coupled with her "extreme" "religious ideology ... in that she was basically choosing to discriminate against a group of people in the name of religion," Davis' physical appearance "drew their attention," Bethany believed. "So, I think that whole package together was really attractive to the media. It's easy for the media also to put down Kentucky as a place of backward hillbillies."

Many news articles also featured images of anti-LGBTQ activists waving flags, Bibles, and guns outside the Rowan County courthouse. Kentuckians have much experience facing and combating stereotypes of rural Appalachians as poor, unsophisticated, and out of touch with popular culture. Unsurprisingly, several participants lamented that Davis's actions reinforced negative stereotypes about the region. Some, like Christine, viewed it as their moral obligation to protest and resist harmful stereotypes of Appalachia that galvanized local homophobia. Christine elaborated:

When we tell people, "I'm from Morehead," two out of three times, people say, "Oh, that place where that Kim Davis lady is from," and that stinks. It doesn't make us look great, but there's also a lot of people that after that say, "Oh, were you there with those people who were out there protesting?" And so that gives us an opportunity to say, "Yeah, there are a lot of good people in our community. They realize when bad things happen, and they know they need to take action." I do think a lot of people think, "They must be stereotypical Kentuckians: backwoods, they're ignorant." But, on the flipside, a lot of people say, "That same day, a bunch of those kids went out there with their signs and their flags, and they protested for what is right."

Several pro-LGBTQ activists stressed that one reason they protested was to remind observers that there are left-leaning progressives in rural Kentucky and to challenge outdated stereotypes of Appalachia. Natalie shared, "We were already being made fun of for being in the Kentucky county that was standing up against [Davis] so there was this negative image of Morehead and Rowan County. It was really important to me that we were representing a better part of Rowan County. I wanted them to see us as passionate, vibrant activists; people that were not stereotypical, but peaceful and respectful." Lesbian, bisexual, pansexual, and queer women activists felt that it was important to challenge the stereotypes of others and model what a progressive community looks like for locals. By participating in daily protests, local LGBTQ residents experienced a greater sense of belonging in the region while challenging negative stereotypes about what makes up a "Kentuckian."

\section{Conclusion}

In Rowan County, Kentucky, pro-equality advocates challenged small-town intolerance and religious homophobia to create a more a progressive space for sexual and gender minorities. Whereas much scholarship on NIMBY 
organizing explores the motivations of sociopolitical conservatives, here we highlight progressive queer women's resistance to religious homophobia in a rural Kentucky community. In doing so, we make a substantive contribution to rural queer (Gray, Johnson, \& Gilley, 2016) and NIMBY studies. As noted, most research on US LGBTQ organizing focuses on major metropolitan areas (Armstrong, 2002; Ghaziani, 2008), excluding rural queer people from national conversations about gender and sexual diversity politics. Our research shifts the center of movement organizing around LGBTQ rights away from the urban by interrupting "metronormative" assumptions guiding queer and social movement studies. Simply stated, our findings counterassumptions that no LGBTQ organizing exists in rural areas. Rather, we find that norms of rural life can sometimes accelerate social change. In 2015, the spectacularly public events in Rowan County, coupled with the tight-knit structure of small town life, facilitated relationship-building that weakened the toxic closet and made possible future progressive grassroots organizing. The continued persistence of pro-LGBTQ organizing, among other social justice initiatives in Morehead, suggests that the rural US south is a new frontier for LGBTQ activism.

\section{Note}

1. According to 2018 US Census estimates, approximately 94 percent of Rowan County, Kentucky, residents identified as non-Hispanic whites. Therefore, it is unsurprising that all of our respondents identified as white.

\section{Acknowledgments}

The authors thank Anna Blanton, Kathleen M. Blee, Toni Hobbs, Nashia Fife, and all the interview participants for their support of the project. The authors gratefully acknowledge the data collected by, and the support of, MSU's Rowan County Marriage Equality and Religious Liberty Project (MERL). We also acknowledge Research and Sponsored Programs and the Department of Sociology, Social Work and Criminology at Morehead State University and the University of Cincinnati's University Research Council and Charles Phelps Taft Research Center for generously supporting this study. Finally, we thank Emily Kazyak and three anonymous reviewers at the Journal of Lesbian Studies for their thoughtful feedback.

\section{Notes on contributors}

Bernadette Barton is Professor of Sociology and Director of Gender Studies at Morehead State University. She is the author of Stripped: More Stories from Exotic Dancers (2017), Pray the Gay Away: The Extraordinary Lives of Bible Belt Gays (2014), and Raunch Culture (forthcoming).

Ashley Currier is Professor and Head of Women's, Gender, and Sexuality Studies at the University of Cincinnati. She is the author of Politicizing Sex in Contemporary Africa: 
Homophobia in Malawi (2018) and Out in Africa: LGBT Organizing in Namibia and South Africa (2012).

\section{References}

Armstrong, E. A. (2002). Forging gay identities: Organizing sexuality in San Francisco, 19501994. Chicago, IL: University of Chicago Press.

Associated Press. (2015). Kentucky: Clerk ordered to issue wedding licenses to same-sex couples. New York Times. August 13, A10.

Barton, B. (2012). Pray the gay away: The extraordinary lives of Bible belt gays. New York: New York University Press.

Bernstein, M. \& Taylor, V. (Eds). (2013). The marrying kind? Debating same-sex marriage within the lesbian and gay movement. Minneapolis, MN: University of Minnesota Press.

Brown-Saracino, J. (2018). How places make us: Novel LBQ identities in four small cities. Chicago: University of Chicago Press.

Cruz, C. (2011). LGBTQ street youth talk back: A meditation on resistance and witnessing. International Journal of Qualitative Studies in Education, 24(5), 547-558.

Donesky, F. (1999). America needs hillbillies: The case of the Kentucky cycle. In D. B. Billings, G. Norman, \& K. Ledford (Eds.) Back talk from Appalachia: Confronting stereotypes (pp. 283-299). Lexington, KY: University Press of Kentucky.

Forstie, C. (2018). Ambivalently post-lesbian: LBQ friendships in the rural midwest. Journal of Lesbian Studies, 22(1), 54-66.

Ghaziani, A. (2008). The dividends of dissent: How conflict and culture work in lesbian and gay marches on Washington. Chicago, IL: University of Chicago Press.

Gray, M. L. (2009). Out in the country: Youth, media, and queer visibility in rural America. New York, NY: New York University Press.

Gray, M. L., Johnson, C. R., \& Gilley, B. J. (Eds.). (2016). Queering the countryside: New frontiers in rural queer studies. New York, NY: New York University Press.

Hager, C. \& Haddad, M. A. (Eds.). (2015). NIMBY is beautiful: Cases of local activism and environmental innovation around the world. New York, NY: Berghahn.

Halberstam, J. (2005). In a queer time and place: Transgender bodies, subcultural lives. New York, NY: New York University Press.

Jerolmack, C., \& Walker, E. T. (2018). Please in my backyard: Quiet mobilization in support of fracking in an Appalachian community. American Journal of Sociology, 124(2), 479-516.

Kazyak, E. (2011). Disrupting cultural selves: Constructing gay and lesbian identities in rural locales. Qualitative Sociology, 34(4), 561-581.

Luis, K. N. (2018). Herlands: Exploring the women's land movement in the United States. Minneapolis, MN: University of Minnesota Press.

Manalansan, M. F. IV. (2005). Race, violence, and neoliberal spatial politics in the global city. Social Text, 84-85, 141-155.

McAdam, D., \& Tarrow, S. (2018). The political context of social movements. In D. A. Snow, S. A. Soule, H. Kriesi, \& H. J. McCammon (Eds.) The Wiley Blackwell companion to social movements (2nd ed., pp. 19-42). Hoboken, NJ: John Wiley \& Sons.

Myers, D. J. (2008). Ally identity: The politically gay. In J. Refer, D. J. Myers, \& R. L. Einwohner (Eds.) Identity work in social movements (pp. 167-187). Minneapolis, MN: University of Minnesota Press.

Ross, B. L. (2010). Sex and (evacuation from) the city: The moral and legal regulation of sex workers in Vancouver's West End, 1975-1985. Sexualities, 13(2), 197-218. 
Shih, E. (2016). Not in my 'backyard abolitionism': Vigilante rescue against American sex trafficking. Sociological Perspectives, 59(1), 66-90.

Southall, A. (2015). Court rules clerk must issue licenses for same-sex marriages. New York Times, August 27, A15.

Staley, K. (2012). Gay liberation comes to Appalachian State University (1969-1979). Appalachian Journal, 39(1/2), 72-91.

Stein, A. (2001). The stranger next door: The story of a small community's battle over sex, faith, and civil rights. Boston, MA: Beacon.

Stone, A. L. (2018). The geography of research on LGBTQ life: Why sociologists should study the south, rural queers, and ordinary cities. Sociology Compass, 12(11), e12638.

Taylor, V., \& Whittier, N. E. (1992). Collective identity in social movement communities: Lesbian feminist mobilization. In A. D. Morris \& C. M. Mueller (Eds.) Frontiers in social movement theory (pp. 104-129). New Haven, CT: Yale University Press.

Williams, M. (2018). The sex offender housing dilemma: Community activism, safety, and social justice. New York, NY: New York University Press. 